\title{
ANALISIS KEMAMPUAN CALON GURU MATEMATIKA DALAM MENERAPKAN PENDEKATAN SAINTIFIK BERDASARKAN KURIKULUM 2013
}

\author{
Mohammad Tohir ${ }^{1)}$, A. Wida Wardani ${ }^{2)}$ \\ ${ }^{1)}$ Universitas Jember, ${ }^{1), 2}$ Guru SMP Negeri 2 Jember \\ ${ }^{1)}$ matematohir@gmail.com
}

\begin{abstract}
Abstrak. Penelitian ini bertujuan untuk memperoleh deskripsi kemampuan calon guru matematika dalam menerapkan pendekatan saintifik pada kegiatan pembelajaran di kelas. Penelitian ini merupakan penelitian deskriptif kualitatif. Subjek penelitian adalah calon guru matematika (guru PPL) yang magang di SMP Negeri 2 Jember. Teknik pengumpulan data yang digunakan adalah kuesioner, wawancara, observasi, dan hasil supervisi pada saat ujian praktik. Teknik analisis data dalam penelitian ini menggunakan checklist dan alur analisis model Miles dan Huberman. Hasil penelitian menunjukkan bahwa: (1) pemahaman guru PPL tentang model pembelajaran melalui pendekatan saintifik diperoleh sebanyak $28,57 \%$ berada pada kategori mampu dan sebanyak $71,43 \%$ berada pada kategori cukup mampu; (2) kemampuan guru PPL dalam menyusun perangkat pembelajaran sesuai dengan struktur kurikulum 2013 diperoleh sebanyak 100\% berada pada kategori mampu; (3) kemampuan guru PPL dalam melaksanakan kegiatan pembelajaran dengan menggunakan pendekatan saintifik diperoleh sebanyak $57,14 \%$ berada pada kategori mampu dan sebanyak $42,86 \%$ berada pada kategori cukup mampu; (4) kemampuan guru PPL dalam menyusun dan melaksanakan penilaian autentik diperoleh sebanyak $28,57 \%$ berada pada kategori mampu dan sebanyak $71,43 \%$ berada pada kategori cukup mampu; (5) respon siswa terhadap guru PPL selama mengajar (magang) diperoleh sebanyak $42,86 \%$ berada pada kategori sangat sesuai dengan karakteristik siswa sebagai guru matematika dan sebanyak $57,14 \%$ berada pada kategori sesuai dengan dengan karakteristik siswa sebagai guru matematika. Sedangkan hambatan yang dialami oleh guru PPL adalah minimnya pengalaman dalam menerapkan pendekatan saintifik pada pembelajaran terutama pada kegiatan bertanya dan menalar, pengaturan alokasi waktu, dan masih kesulitan dalam melakukan penilaian yang berdasarkan Kurikulum 2013.
\end{abstract}

Kata Kunci: Kemampuan, Guru PPL, Pendekatan Saintifik, Kurikulum 2013.

\section{Pendahuluan}

Kualitas pendidikan matematika di Indonesia masih sangat memprihatinkan dibandingkan dengan negara-negara lain. Salah satu indikatornya adalah keikutsertaan Indonesia di dalam studi Internasional Trends in International Mathematics and Science Study (TIMSS) dan Programme International for Student Assesment (PISA) menunjukkan bahwa capain anak-anak Indonesia tidak menggembirakan. Fakta dari hasil pengujian PISA tentang literasi matematika, pada tahun 2000, 2003, 2006, dan 2009, berturut-turut rata-rata skor siswa Indonesia adalah 367 (urutan 39 dari 41 negara), 360 (urutan 38 dari 40 negara), 391 (urutan 50 dari 57 negara), 371 (urutan 61 dari 65 negara) dan 375 (urutan 64 dari 65 negara). Pada PISA 2012 untuk literasi matematika, Indonesia menempati urutan 64 dari 65 (OECD, 2013). Lebih lanjut pada PISA 2012 dipaparkan bahwa siswa Indonesia dalam level $1-6$, sekitar 75,7\% hanya mampu mencapai level 1 atau 2 dan hanya $0,3 \%$ yang mampu mencapai level 5 atau 6 , sementara siswa-siswa Korea, hanya sekitar 9,1\% yang berada pada level 1 atau 2 dan 30,9\% mencapai level 5 atau 6 . Dengan keyakinan bahwa semua anak dilahirkan sama, kesimpulan dari hasil ini adalah apa yang diajarkan atau bagaimana mengajarkannya di Indonesia berbeda dengan yang diujikan bersatndart internasional (Kemdikbud, 2013).

Data-data tersebut di atas maknanya terdapat masalah dalam sistem pendidikan Indonesia, pertama; masalah mendasar yakni kekeliruan paradigma pendidikan yang mendasari keseluruhan penyelenggaraan 
sistem pendidikan, kedua; masalah-masalah lain, yaitu berbagai problem yang berkaitan dengan aspek praktis/teknis penyelenggaraan pendidikan misalnya; biaya pendidikan, rendahnya sarana fisik, rendahnya kesejahteraan guru, rendahnya kualitas guru dan rendahnya prestasi siswa, dan sebagainya. Oleh karena itu Pemerintah Indonesia selalu berupaya untuk meningkatkan kualitas pendidikan Indonesia dengan melakukan perubahan kurikulum dari 1994, KBK, KTSP, dan menjadi Kurikulum 2013. Pengembangan kurikulum adalah proses pendidikan yang utama bagi pengembangan pendidikan sekolah karena pembelajaran harus dirancang untuk memenuhi kebutuhan (Primrose dan Alexander, 2013).

Peningkatan kualitas pembelajaran bagi calon guru matematika sengat dibutuhkan agar sebagai calon pendidik dapat meningkatkan kualitas pembelajaran dan pendidikan yang ada di Indonesia. Apalagi mahasiswa PPL (Program Pengalaman Lapangan) masih sangat minim pengetahuannya tentang kurikulum 2013, maka dari itu perlu adanya bimbingan, arahan dan motovasi dalam melaksanakan kegiatan pembelajaran yang sesuai dengan kurikulum 2013 dengan menggunakan model pembelajaran pendekatan saintifik. Dengan demikian, calon guru harus mampu mempraktikkan ilmu yang didapat ketika di kampus sehngga mampu dalam melaksanakan tugas sebagai pengajar dan pendidik. Menurut Sulaiman (1979), guru harus memiliki kemampuan melaksanakan tugas sebagai pendidik, pengajar, dan pelatih. Sebagai seorang pengajar, guru dituntut untuk dapat merencanakan proses pembelajaran yang meliputi penggunaan metode atau model pembelajaran, penggunaan media pembelajaran, dan penilaian proses pembelajaran. Sedangkan menurut Usman (1992) terdapat delapan keterampian dasar mengajar yaitu: (1) keterampilan bertanya, (2) keterampilan memberi penguatan, (3) keterampilan mengadakan variasi, (4) keterampilan menjelaskan, (5) keterampilan membuka dan menutup pelajaran, (6) keterampilan membimbing diskusi kelompok kecil, (7) keterampilan mengelola kelas, dan (8) keterampilan mengajar perseorangan. Kedelapan keterampilan dasar mengajar ini dapat diamati ketika seorang guru sedang mengajar di kelas dengan menggunkan lembar pengamatan kualitas mengajar. Sebagai seorang guru yang profesional, maka tentunya sebelum mengajar ada beberapa hal yang harus dipersiapkan, diantaranya adalah perangkat pembelajaran yang terdiri dari metodologi pengajaran yang menyangkut beberapa unsur seperti mempersiapkan bahan yang akan diajarkan, memilih metode yang tepat, dan menggunakan media yang sesuai.

Sedangkan implementasi Kurikulum 2013 dalam proses pembelajarannya adalah menggunakan pendekatan scientific. Pembelajaran scientific dapat didefinisikan sebagai pembelajaran yang dirancang sedemikian rupa sehingga peserta didik secara aktif mengkonstruk konsep, hukum, atau prinsip melalui langkahlangkah mengamati, merumuskan pertanyaan, mengumpulkan data/informasi, mengolah/menganalisis data/ informasi, menarik kesimpulan dan mengkomunikasikan kesimpulan (Endang Mulyani, 2013: 3). Namun, untuk mata pelajaran tertentu ada langkah pembelajaran keenam yaitu mencipta, seperti untuk mata pelajaran kesenian.

Pendekatan scientific sesuai Kurikulum 2013 memiliki beberapa tujuan dalam proses pembelajarannya. Berikut ini tujuan pembelajaran dengan pendekatan scientific antara lain.

1) Meningkatkan kemampuan berpikir kritis peserta didik.

2) Membentuk kemampuan peserta didik dalam menyelesaikan suatu masalah secara sistematik.

3) Melatih peserta didik dalam mengkomunikasikan ide-ide.

4) Meningkatkan kreativitas peserta didik.

5) Mengembangkan karakter peserta didik (Endang Mulyani, (2013: 3)

Dalam pelaksanaan pembelajaran scientific, secara umum ada tiga kegiatan pembelajaran yaitu kegiatan pendahuluan, kegiatan inti, dan kegiatan penutup. Kegiatan pendahuluan bertujuan untuk menciptakan suasana awal pembelajaran yang efektif yang memungkinkan siswa dapat mengikuti proses pembelajaran dengan baik (Endang Mulyani, 2013: 4). Sedangkan kegiatan inti merupakan kegiatan utama dalam proses pembelajaran yang ditunjukan untuk terkonstruksinya konsep, hukum, atau prinsip oleh peserta didik dengana bantuan guru melalui langkah-langkah mengamati, menanya, mengumpulkan data/informasi, menalar, mengkomunikasikan dan mencipta. Terakhir, kegiatan penutup yang ditujuakan untuk menutup kegiatan pembelajaran yang berlangsung, biasanya dilakukan beberapa kegiatan seperti post test, remidial, atau pengayaan.

Berikut ini penjelasan beberapa jenis model pembelajaran berdasarkan pendekatan scientific Kurikulum 2013 dalalah sebagai berikut.

1) Pembelajaran Berbasis Masalah (Problem-Based Learning)

Menurut Endang Mulyani (2013: 7) Pembelajaran Berbasis Masalah adalah pembelajaran yang menggunakan masalah nyata sebagai sarana bagi peserta didik untuk mengembangkan keterampilan meyelesaikan masalah dan berpikir kritis serta membangun pengetahuan baru.

2) Pembelajaran Berbasis Projek (Project-Based Learning) 
Menurut Endang Mulyani (2013: 9) Pembelajaran Berbasis Projek adalah model pembelajaran yang menggunakan projek sebagai proses pembelajaran untuk mencapai kompetensi sikap, pengetahuan, dan keterampilan.

3) Model Pembelajaran Discovery

Menurut Endang Mulyani (2013: 11) model pembelajaran discovery adalah proses pembelajaran yang terjadi bila peserta didik tidak disajiakan dengan pembelajaran dalam bentuk finalnya, tetapi diharapkan peserta didik mengorganisasi sendiri.

4) Model Pembelajaran Inquiry

Menurut Kuslan Stone (Dahar, 1991) yang dikutip oleh Saliman mendefinisikan model inkuiri sebagai pengajaran di mana guru dan anak mempelajari peristiwaperistiwa dan gejala-gejala ilmiah dengan pendekatan dan jiwa para ilmuwan. Pengajaran berdasarkan inkuiri adalah suatu strategi yang berpusat pada siswa di mana kelompokkelompok siswa dihadapkan pada suatu persoalan atau mencari jawaban terhadap pertanyaan-pertanyaan di dalam suatu prosedur dan struktur kelompok yang digariskan secara jelas.

Berdasarkan latar belakang di atas, maka diperlukan adanya suatu reasech tertentu tentang kemampuan dan kesiapan guru PPL dalam menghadapi kurikulum yang selalu dikembangkan dengan judul: Analisis Kemampuan Calon Guru Matematika dalam Menerapkan Pendekatan Saintifik Berdasarkan Kurikulum 2013.

Adapun rumusan masalah yang akan dibahas dalam artikel ini, yaitu: (1) Bagaimana pemahaman calon guru matematika terhadap pendekatan saintifik yang sesuai dengan kurikulum 2013?, (2) Bagaimana kemampuan calon guru matematika dalam menyusun perencanaan pembelajaran berbasis pendekatan saintifik berdasarkan Kurikulum 2013?, (3) Bagaimana kemampuan calon guru matematika dalam melaksanakan pembelajaran degan menggunakan pendekatan saintifik berdasarkan Kurikulum 2013?, (4) Bagaimana kemampuan calon guru matematika dalam melaksanakan penilaian autentik dengan menggunakan pendekatan saintifik berdasarkan Kurikulum 2013?, dan (5) Bagaiamana respon siswa terhadap calon guru matematika selama proses pembelajaran dengan menggunakan pendekatan saintifik berdasarkan Kurikulum 2013?

\section{Metode Penelitian}

Metode penelitian merupakan penelitian kualitatif. Penelitian kualitatif memiliki ciri-ciri yaitu mempunyai latar belakang alamiah (konteks dari suatu keutuhan), manusia sebagai alat atau instrumen, menggunakan metode kualtitatif, analisis data secara induktif, penyusunan teori berdasarkan data, data bersifat deskriptif, lebih mementingkan proses dari pada hasil, adanya batas yang ditentukan oleh fokus, adanya kriteria khusus untuk keabsahan data, desain bersifat sementara, dan hasil penelitian merupakan hasil keputusan bersama (Moleong, 2013).

Subjek penelitiahan yang dilakukan oleh penulis adalah caru guru matematika atau guru PPL yang mengajar matematika dan magang di SMP Negeri 2 Jember dengan jumlah mahasiswa sebanyak 7 orang dari Uninersitas Jember.

Teknik pengumpulan data yang diperlukan dalam penelitian ini, peneliti menggunakan teknik pengumpulan data dengan kuesioner/angket. Menurut Sugiyono (2013: 199) "kuesioner merupakan teknik pengumpulan data yang dilakukan dengan cara memberi seperangkat pertanyaan atau pertanyaan tertulis kepada responden untuk dijawabnya". Bentuk kuesioner dalam penelitian ini adalah tertutup, yaitu sudah disediakan jawabannya sehingga responden tinggal memilih jawaban yang telah disediakan peneliti. Teknik pengumpulan data ini dipilih oleh peneliti karena teknik kuesioner merupakan teknik pengumpulan data yang memudahkan responden dalam menjawab dan cukup efisien untuk mengetahui dengan pasti variabel yang akan diukur.

Data yang digunakan pada penelitian ini adalah data primer. Menurut Saifuddin Azwar (2004: 91) data primer atau data pertama adalah data yang diperoleh langsung dari subjek penelitian dengan mengenakan alat pengukuran atau alat pengambilan data langsung pada subjek sebagai sumber informasi yang dicari. Jadi, dalam memperoleh data ini peneliti langsung mengetahui yang sebenarnya terjadi dilapangan mulai dari persiapan, perencanaan, pelaksanaan, dan penilaian outentik, karena peneliti merupakan guru pamong dari guru PPL tersebut.

Sedangkan Instrumen merupakan alat yang digunakan oleh peneliti untuk mengumpulkan data agar penelitian dan hasilnya mudah diolah. Cara pengumpulan data pada penelitian ini adalah dengan kuesioner atau angket. Dalam penelitian ini, kuesioner disajikan dalam bentuk skala Likert dengan menggunakan empat kategori atau alternatif jawaban. Skala Likert ini telah banyak digunakan oleh para peneliti guna mengukur persepsi atau sikap sesorang (Hamid Darmadi, 2011: 106). Untuk mempermudah analisis, empat alternatif 
jawaban tersebut dibuat nilai dengan skor 1, 2, 3, dan 4. Pada tabel 1 berikut ini adalah penjelasan skor untuk tiap-tiap alternatif jawaban tersebut.

Tablel 1. Kategori dan Skornya

\begin{tabular}{ccc}
\hline Kategori & & Skor \\
\hline Tidak Mampu & TM & 1 \\
Mampu & CM & 2 \\
Cukup Mampu & M & 3 \\
Sangat Mampu & SM & 4 \\
\hline
\end{tabular}

Dalam penelitian ini, instrumen yang digunakan berupa daftar pertanyaan yang memuat indikator dari variabel penelitian. Indikator tersebut diambil dari indikator dalam implementasi Kurikulum 2013. Di mana ada tiga indikator yang juga menjadi dimensi kesulitan dalam penelitian ini. Tiga dimensi kesulitan ini dianggap mampu mengukur tingkat kesulitan guru dalam pembelajaran berdasarkan Kurikulum 2013. Ketiga dimensi kesulitan tersebut meliputi perencanaan pembelajaran, pelaksanaan (pembelajaran Scientific), dan penilaian otentik.

Menurut Permendikbud Nomor 20 Tahun 2016 tentang Standar Kompetensi Lulusan Pendidikan Dasar dan Menengah digunakan sebagai acuan utama pengembangan standar isi, standar proses, standar penilaian pendidikan, standar pendidik dan tenaga kependidikan, standar sarana dan prasarana, standar pengelolaan, dan standar pembiayaan. Lebih lanjut menyebutkan bahwa proses pembelajaran pada satuan pendidikan diselenggarakan secara interaktif, inspiratif, menyenangkan, menantang, memotivasi peserta didik untuk berpartisipasi aktif, serta memberikan ruang yang cukup bagi prakarsa, kreativitas, dan kemandirian sesuai dengan bakat, minat, dan perkembangan fisik serta psikologis peserta didik. Untuk itu setiap satuan pendidikan melakukan perencanaan pembelajaran, pelaksanaan proses pembelajaran serta penilaian proses pembelajaran untuk meningkatkan efisiensi dan efektivitas ketercapaian kompetensi lulusan sesuai kurikulum yang berlaku.

Analisis data dalam penelitian ini menggunakan check list dan alur analisis model Miles \& Huberman. Kemudian, untuk hasil penelitian yang lebih mendalam dilakukan analisis crosstabs (tabulasi silang) untuk mengetahui kategori calon guru yang bagaimana yang membuat tingkat kemampuan lebih tinggi dalam melakukan pembelajaran matematika dengan menggunakan pendekatan saintifik berdasarkan Kurikulum 2013.

Untuk mendapatkan data penelitian digunakan empat teknik pengumpulan data, yaitu: dokumentasi, kuesioner, wawancara, dan pengamatan. Secara ringkas, teknik dan instrumen penelitian yang sesuai dengan pertanyaan penelitian disajikan pada Tabel 2 .

Tabel 2. Teknik dan Instrumen Pengumpulan Data

\begin{tabular}{|c|c|c|c|c|}
\hline No. & Pertanyaan Penelitian & Sumber Data & Teknik & Intrumen \\
\hline 1. & $\begin{array}{l}\text { Bagaimana pengetahuan calon guru } \\
\text { matematika tentang model } \\
\text { pembelajaran melalui pendekatan } \\
\text { saintifik berdasarkan Kurikulum } 2013 \text { ? }\end{array}$ & Guru PPL & $\begin{array}{l}\text { Kuesioner } \\
\text { Wawancara }\end{array}$ & $\begin{array}{l}\text { Kuesioner } \\
\text { Pertanyaan } \\
\text { wawancara }\end{array}$ \\
\hline 2. & $\begin{array}{l}\text { Bagaimana calon guru matematika } \\
\text { dalam menyusun perangkat } \\
\text { pembelajaran yang sesuai dengan } \\
\text { struktur kurikulum } 2013\end{array}$ & Guru PPL & $\begin{array}{l}\text { Dokumentasi } \\
\text { Wawancara }\end{array}$ & $\begin{array}{l}\text { Panduan analisis } \\
\text { RPP }\end{array}$ \\
\hline 3. & $\begin{array}{l}\text { Bagaimana calon guru matematika } \\
\text { dalam melaksanakan pembelajaran } \\
\text { degan menggunakan pendekatan } \\
\text { saintifik berdasarkan Kurikulum } 2013\end{array}$ & Guru PPL & $\begin{array}{l}\text { Dokumentasi } \\
\text { Wawancara } \\
\text { Pengamatan }\end{array}$ & $\begin{array}{l}\text { Pertanyaan } \\
\text { wawancara } \\
\text { Checklist } \\
\text { Kamera, HP } \\
\text { Video recording }\end{array}$ \\
\hline 4. & $\begin{array}{l}\text { Bagaimana calon guru matematika } \\
\text { dalam melaksanakan penilaian autentik }\end{array}$ & Guru PPL & $\begin{array}{l}\text { Dokumentasi } \\
\text { Wawancara }\end{array}$ & $\begin{array}{l}\text { Kuesioner } \\
\text { wawancara }\end{array}$ \\
\hline
\end{tabular}




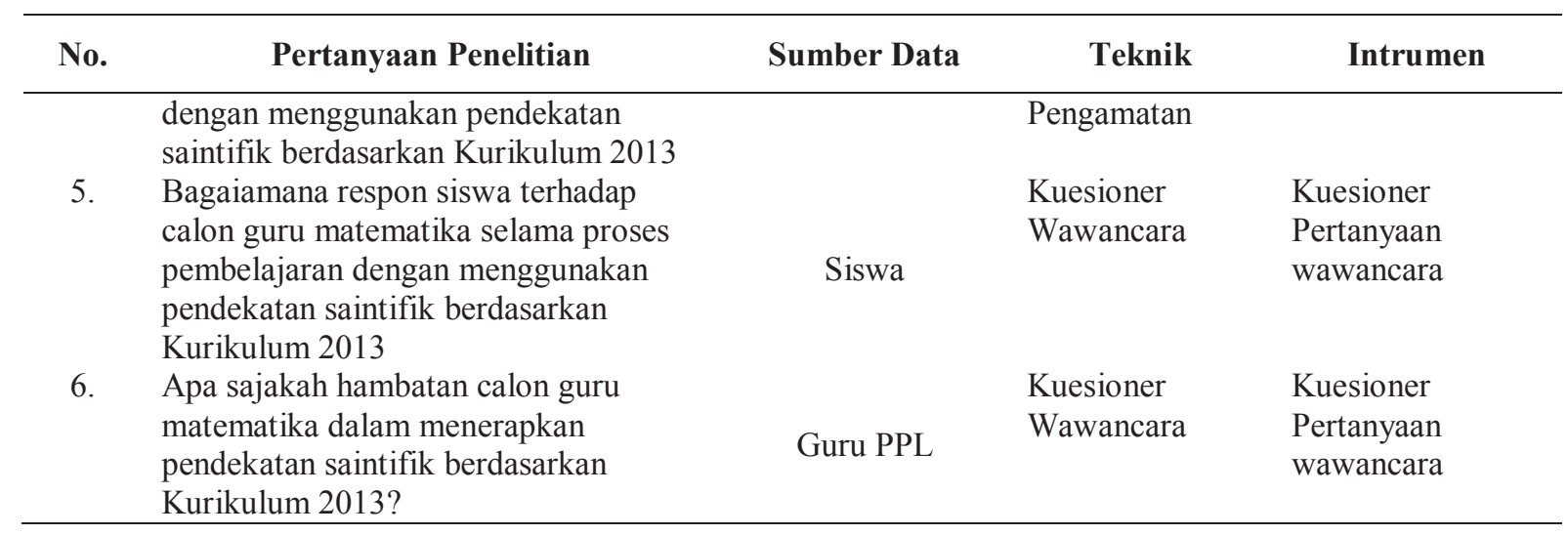

Sedangkan dalam penelitian ini menggunakan pengujian keabsahan data, meliputi: derajat kepercayaan (credibility), keteralihan (transferability), kebergantungan (dependability), dan kepastian (confirmability) (Sugiyono, 2013). Analisis data dalam penelitian ini menggunakan check list dan alur analisis data model Miles \& Huberman.

\section{Hasil Penelitian}

Penelitian ini dimaksudkan untuk mengetahui gambaran mengenai tingkat kemampuan calon guru dalam pembelajaran matematika dengan menggunakan model pendekatan saintifik berdasarkan Kurikulum 2013. Penelitian ini menyajikan temuan data setiap kasus dari subjek penelitian, yaitu: calon Guru $A$, calon Guru $B$, calon Guru $C$, calon Guru $D$, calon Guru $E$, calon Guru $F$, dan calon Guru $G$. Hasil pengukuran tingkat kemampuan guru PPL dalam pembelajaran matematika dalam menerapkan model pembelajaran melalui pendekatan saintifik berdasarkan Kurikulum 2013 untuk tiap-tiap dimensi kampuan (pengetahuan, perencanaan, pelaksanaan, dan penilaian pembelajaran) adalah sebagai berikut.

\section{Analisis Data pada Deminsi Pengetahuan tentang Pendekatan Saintifik}

Pendekatan Saintifik atau ilmiah merupakan suatu cara atau mekanisme pembelajaran untuk memfasilitasi siswa agar mendapatkan pengetahuan atau keterampilan dengan prosedur yang didasarkan pada suatu metode ilmiah (Kemdikbud, 2015). Temuan-temuan data tentang pengetahuan calon guru matematika tentang model pembelajaran melalui pendekatan saintifik berdasarkan Kurikulum 2013 diperoleh melalui kuesioner, wawancara, dan observasi dapat disajikan pada Tabel 3. Tabel 3. Pengetahuan tentang pendekatan saintifik

\begin{tabular}{ccccc}
\hline No. & Guru & Skor & Prosentase & Kategori \\
\hline 1. & A & 2,25 & 56,25 & Cukup Mampu \\
2. & B & 2,75 & 68,75 & Mampu \\
3. & C & 2,50 & 62,50 & Cukup Mampu \\
4. & D & 2,25 & 56,25 & Cukup Mampu \\
5. & E & 2,25 & 56,25 & Cukup Mampu \\
6. & F & 2,75 & 68,75 & Mampu \\
7. & G & 2,25 & 56,25 & Cukup Mampu \\
\hline
\end{tabular}

Berdasarkan Tabel 3, hasil analisis pengetahuan subjek penelitian terhadap pengetahuan calon guru matematika tentang model pembelajaran melalui pendekatan saintifik berdasarkan Kurikulum 2013 memperlihatkan bahwa Guru B dan F masuk dalam kategori "Mampu". Sedangkan Guru A, C, D, E dan G masuk dalam kategori "Cukup Mampu". Hal ini menggambarkan bahwa pengetahuan guru PPL tentang model pembelajaran melalui pendekatan saintifik masih perlu ditingkatkan agar dapat menjalankan kegiatan saintifik yang sesuai rancangan pemerintah dalam kurikulum 2013. 
Pengetahuan tentang pendekatan saintifik yang berdasarkan kurikulum 2013 akan mengarahkan guru PPL dalam menerapkan pembelajaran di kelas. Pengetahuan awal tentang pendekatan saintifik merupakan kontrol dalam menerapakan pembelajaran di kelas degan menggunakan pendekatan saintifik. Seperti ungkapan oleh Leonardo da Vinci (Lewis Einstein, 2008) "Mereka yang menyukai praktik tanpa teori bagaikan pelaut yang menjalankan kapal tanpa kompas dan kemudian, mereka tidak pernah tahu di mana akan terdampar." Oleh karena itu, pengetahuan awal tentang pendekatan saintifik sangatlah penting bagi calon guru dalam mempraktekkan di dalam kelas. Namun ada satu subjek penelitian yang masuk pada kategori tidak mampu, peneliti menelusuri melalui wawancara dengan subjek penelitian, berikut salah satu kutipan wawancara dengan subjek penelitian.

Peneliti: "menurut bapak, karakteristik tertentu apa saja dalam kurikulum 2013 yang membedakan dengan kurikulum Lainnya?"

Guru A: "yang saya tahu Pak, kalau kurikulum 2013 sebagai acuan dalam proses dan hasil belajar, sedangkan kalau kurikulum yang lainnya acuannya adalah hasil pembelajaran saja"

Berdasarkan hasil wawancara tersebut menunjukkan bahwa ada satu subjek penelitian yang belum mengetahui tentang salah satu karakteristik kurikulum 2013 dengan kurikulum lainnya. Temuan melalui wawancara ini kalau dibiarkan akan berdampak kurang optimal dalam menerapkan pendekatan saintifik yang berdasarkan kurikulum 2013 baik dalam merancang pembelajaran, pelaksanaan pembelajaran, maupun dalam menyusun dan melakukan penilaian autentik. Guru dengan pengetahuan kurikulum yang kuat akan mengetahui keadaan atau standar nasional untuk pembelajaran matematika dan merencanakan kegiatan pembelajaran dengan tepat (Kilic, 2011). Sedangkan Manurut Mulyasa (2014) menyatakan bahwa guru matematika yang melakukan pembelajaran di kelas adalah kurikulum. Dengan adanya temuan seperti ini, kemudian peneliti yang sekaligus sebagai guru pamong memberikan bimbingan dan arahan tentang karakteristik tertentu apa saja dalam kurikulum 2013 yang membedakan dengan kurikulum lainnya. Kalau dilihat dari poin kurikulumnya dalam kurukulum 2013, kurikulum itu adalah turunan dari SKL, SI, Proses, Penilaian. Sedangkan pada kurikulum lainnya, kurikulum itu adalah bagian dari Standar Isi (Kemendibud, 2013).

\section{Analisis Data pada Deminsi Perencanaan Pembelajaran}

Rencana Pelaksanaan Pembelajaran (RPP) adalah rencana kegiatan pembelajaran tatap muka untuk satu pertemuan atau lebih. RPP dikembangkan dari silabus untuk mengarahkan kegiatan pembelajaran peserta didik dalam upaya mencapai Kompetensi Dasar (KD). Setiap pendidik pada satuan pendidikan berkewajiban menyusun RPP secara lengkap dan sistematis agar pembelajaran berlangsung secara interaktif, inspiratif, menyenangkan, menantang, efisien, memotivasi peserta didik untuk berpartisipasi aktif, serta memberikan ruang yang cukup bagi prakarsa, kreativitas, dan kemandirian sesuai dengan bakat, minat, dan perkembangan fisik serta psikologis peserta didik. RPP disusun berdasarkan KD atau subtema yang dilaksanakan kali pertemuan atau lebih (Permendikbud No.22, 2016). Temuan-temuan data tentang perencanaan pembelajaran yang disusun oleh calon guru matematika berdasarkan Kurikulum 2013 diperoleh melalui kuesioner, wawancara, dan observasi dapat disajikan pada Tabel 4.

Tabel 4. Perencanaan Pembelajaran berdasarkan kurikulum 2013

\begin{tabular}{ccccc}
\hline No. & Guru & Skor & Prosentase & Kategori \\
\hline 1. & A & 2,73 & 68,33 & Mampu \\
2. & B & 2,88 & 71,88 & Mampu \\
3. & C & 2,98 & 74,58 & Mampu \\
4. & D & 2,68 & 67,08 & Mampu \\
5. & E & 2,71 & 67,71 & Mampu \\
6. & F & 3,13 & 78,33 & Mampu \\
7. & G & 2,70 & 67,50 & Mampu \\
\hline
\end{tabular}


Berdasarkan Tabel 4, hasil analisis pada deminsi Perencanaan Pembelajaran berdasarkan kurikulum 2013 memperlihatkan bahwa semua subjek penelitian masuk dalam kategori "Mampu". Dimana hasil untuk semua subjek penelitian tersebut sesuai dengan pendapat Efendi (2009) yang menjelaskan bahwa kegiatan pembelajaran memuat rangkaian kegiatan yang harus dilakukan oleh peserta didik secara berurutan untuk mencapai kompetensi dasar. Hal ini menggambarkan bahwa dokumen RPP yang disusun oleh Guru PPL masih ada beberapa bagian yang perlu diperbaiki atau dikembangkan dan ada beberapa bagian yang sudah baik. Sehingga dokumen RPP yang telah disusun oleh Guru PPL sudah bisa digunakan dalam proses pembelajaran dengan adanya beberapa catatan yang perlu direvisi. Bagian-bagian yang perlu diperbaik oleh Guru PPL adalah kesesuaian media pembelajaran dengan karekteristik pesertadidik, kesuaian strategi pembelajarn dengan materi yang dibahas, kesesuaian materi dengan alokasi waktu, dan kesesuaian rubrik penilaian dengan strategi pembelajaran. Hal ini sesuai dengan salah satu prinsip-prinsip penyusunan RPP (Permendikbud No.22, 2016) bahwa Penekanan pada keterkaitan dan keterpaduan antara KD, materi pembelajaran, kegiatan pembelajaran, indicator pencapaian kompetensi, penilaian, dan sumber belajar dalam satu keutuhan pengalaman belajar. Hal ini juga sejalan dengan pendapat Niron (2009) yang mengatakan bahwa Perencanaan pembelajaran harus berdasarkan pada pendekatan sistem yang mengutamakan keterpaduan antara tujuan/kompetensi, materi, kegiatan belajar dan evaluasi. Salah satu tujuan pembelajaran akan dapat dicapai dengan melalui penyusunan RPP yang baik dan dapat menyediakan pengalaman belajar peserta didik yang baik pula. Penyusunan RPP dapat menolong guru untuk memikirkan pelajaran sebelum pelajaran itu diajarkan sehingga kesulitan belajar dapat diramalkan dan dicari jalan keluarnya (Mulyasa, 2014). Penyusunan Rencana Pelaksanaan Pembelajaran dilakukan berdasarkan prinsip-prinsip pengembangan RPP yang tertera pada Permendikbud yang berlaku dan pelaksanaannya menerapkan pendekatan saintifik dan penilaian autentik (Kemendikbud, 2015).

Hasil analisis dokumen RPP menunjukkan indikasi linier dengan pengetahuan konsep Kurikulum 2013 yang dimiliki subjek penelitian, yakni dalam kategori "Mampu". Hal ini sesuai dengan pernyataan Kilic (Kilic, 2011) bahwa guru dengan pengetahuan kurikulum yang baik akan mampu merencanakan kegiatan pembelajaran dengan tepat. Namun, ada temuan data yang bertentangan dengan pernyataan Kilic (Kilic, 2011), peneliti menelusuri melalui wawancara dengan subjek penelitian, berikut salah satu kutipan wawancara dengan subjek penelitian.

Peneliti: "Bagaimana Bapak dalam menyusun perangkat pembelajaran yang sesuai dengan struktur kurikulum 2013?"

Guru E: "Kami dalam menyusun RPP berdasarkan contoh RPP yang Bapak/Ibu berikan ke kami sebagai contoh RPP untuk kami, selanjutnya kami menyusun RPP yang kemudian kami konsultasikan dengan Bapak/Ibu sebagai guru pamong kami”

Peneliti: "Bagaimana Bapak dalam menyusun perangkat pembelajaran yang sesuai dengan struktur kurikulum 2013?"

Guru F: "Dalam menyusun RPP, kami memadukan pengetahuan kami di kampus dengan contoh RPP yang kami terima dari bapak/Ibu sebagai Guru pamong, kemudian kami konsultasikan degan Bapak/Ibu"

Peneliti: "Bagaimana Ibu dalam menyusun perangkat pembelajaran yang sesuai dengan struktur kurikulum 2013?”

Guru G: "RPP yang kami susun berdasarkan contoh RPP yang kami minta ke Bapak/Ibu, kemudian kami musyawarakan dengan teman-teman kami yang kemudian kami konsultasikan dengan Bapak/Ibu sebagai guru pamong"

Berdasarkan hasil wawancara tersebut menunjukkan bahwa mayoritas subjek penelitian dalam menyusun RPP masih bergantung pada contoh RPP yang diberikan oleh Guru pamong dan masih selalu membutuhkan arahan, bimbingan, dan masukan dari guru pamong. Tapi ada juga subjek yang sudah mencoba mengembangkan RPP berdasarkan pengetahuannya dan masukan dari teman-temannya. Sehingga para Guru PPL saling bertukar pendapat tentang penyusunan RPP. Hal ini ternyata menunjukkan hasil yang positif untuk subjek penelitian dalam merencanakan pembelajaran yang sesuai dengan struktur kurikulum 2013. 


\section{Analisis Data pada Deminsi Pelaksanaan Pembelajaran}

Kegiatan pembelajaran yang berdasarkan kurikulum 2013 harus melalui tiga ranah, yaitu ranah sikap, pengetahuan, dan keterampilan yang dielaborasi untuk setiap satuan pendidikan. Ketiga ranah kompetensi tersebut memiliki lintasan perolehan (proses psikologis) yang berbeda. Sikap diperoleh melalui aktivitas "menerima, menjalankan, menghargai, menghayati, dan mengamalkan". Pengetahuan diperoleh melalui aktivitas "mengingat, memahami, menerapkan, menganalisis, mengevaluasi, mencipta". Keterampilan diperoleh melalui aktivitas "mengamati, menanya, mencoba, menalar, menyaji, dan mencipta". Karaktersitik kompetensi beserta perbedaan lintasan perolehan turut serta mempengaruhi karakteristik standar proses. Untuk memperkuat pendekatan ilmiah (scientific), tematik terpadu (tematik antar matapelajaran), dan tematik (dalam suatu mata pelajaran) perlu diterapkan pembelajaran berbasis penyingkapan/penelitian (discovery/inquiry learning). Untuk mendorong kemampuan peserta didik untuk menghasilkan karya kontekstual, baik individual maupun kelompok maka sangat disarankan menggunakan pendekatan pembelajaran yang menghasilkan karya berbasis pemecahan masalah (project based learning) (Permendikbud No.22, 2016). Temuan-temuan data tentang pelaksanaan pembelajaran dengan menggunakan pendekatan saintifik berdasarkan Kurikulum 2013 diperoleh melalui kuesioner, wawancara, observasi, dan penilaian ujian praktik (hasil sopervisi) dapat disajikan pada Tabel 5.

Tabel 5. Pelaksanaan Pembelajaran berdasarkan kurikulum 2013

\begin{tabular}{ccccc}
\hline No. & Guru & Skor & Prosentase & Kategori \\
\hline 1. & A & 2,47 & 61,69 & Cukup Mampu \\
2. & B & 2,78 & 69,38 & Mampu \\
3. & C & 2,87 & 71,63 & Mampu \\
4. & D & 2,33 & 58,13 & Cukup Mampu \\
5. & E & 2,66 & 66,44 & Mampu \\
6. & F & 2,97 & 74,25 & Mampu \\
7. & G & 2,43 & 60,75 & Cukup Mampu \\
\hline
\end{tabular}

Berdasarkan Tabel 5, hasil analisis pada deminsi pelaksanaa pembelajaran dengan menggunakan pendekatan saintifik berdasarkan kurikulum 2013 memperlihatkan bahwa Guru B, C, E dan F masuk dalam kategori "Mampu". Sedangkan Guru A, D, dan G masuk dalam kategori "Cukup Mampu". Hal ini menggambarkan bahwa pelaksanaa pembelajaran dengan menggunakan pendekatan saintifik berdasarkan kurikulum 2013 masih perlu ditingkatkan lagi agar pembelajaran sesuai dengan yang diharapkan.

Para Guru PPL yang masuk dalam kategori "Cukup Mampu”, pelaksanaan pembelajaran dengan menggunakan pendekatan saitifik masih lebih dominan guru yang aktif, dan masih mengandalkan pembelajarn model ceramah. Padahal hal ini bertentangan dengan karakteristik kurikulum 2013 yang menekankan siswa aktif. Subjek penelitian sangat bergantung pada sumber belajar berupa buku matematika untuk Kurikulum 2013 sebagai sumber belajar, informasi utama, dan panduan pendekatan saintifik sehingga kreativitas subjek penelitian belum tereksplor secara mendalam. Hasil ini tidak sesuai pendapat Marsigit (2014) yang menyatakan bahwa sebenar-benarnya perangkat pembelajaran termasuk buku teks yang terbaik adalah jika buku teks tersebut merupakan karya guru sendiri.

Sedangkan Para Guru PPL yang termasuk dalam kategori "Mampu", pelaksanaan pembelajaran dengan menggunakan pendekatan saitifik sudah mulai berusaha dalam menerapkan berdasarkan karakteristik kurikulum 2013 yang sebenarnya, tapi masih banyak kendala yang dialami dalam pelaksanaannya, diantaranya adalah pada kegiatan mangamati, masih fifti-fifti antara guru yang aktif dengan siswa yang aktif. Pembelajaran pada Kurikulum 2013 menggunakan pendekatan saintifik atau pendekatan berbasis proses keilmuan. Pendekatan saintifik dapat menggunakan beberapa strategi seperti pembelajaran kontekstual. Adapun model pembelajaran merupakan suatu bentuk pembelajaran yang memiliki nama, ciri, sintak, pengaturan, dan budaya misalnya discovery learning, project-based learning, problem-based learning, inquiry learning. Kegiatan pembelajaran dapat menggunakan 
pendekatan saintifik yang disesuaikan dengan karakteristik mata pelajaran dan siswa (Permendikbud Nomor 103 Tahun 2014).

Salah satu tujuan dari kurikulum 2013 adalah terlaksananya penyampaian pesan karakter atau KI-1 dalam setiap pembelajaran dan pesan ini harus terbuka dalam penyampaiannya. Hasil observasi dan supervisi yang didapat oleh penulis pada bagian ini adalah secara umum subjek penelitian masih secara implisit dalam menyampaikan pesan karakter kepada siswa melalui kegiatan pembelajaran seperti diskusi, pemberian tugas, dan bertanya. Subjek penelitian belum menggali nilai-nilai karakter terintegrasi dari materi pelajaran. Hal ini tidak sesuai dengan pendapat Ernest (1998) yang menyatakan bahwa matematikawan mempunyai sebuah perlengkapan nilai-nilai yang kuat terpusat pada matematika. Pendapat tersebut diperkuat oleh pernyataan Department of Education (2002) bahwa matematika adalah sebuah aktivitas yang mempunyai tujuan tertentu dalam konteks sosial, politik, dan ekonomi. Hal ini juga sangat bertentangan dengan karateristik kurikulum 2013, yaitu mengembangkan keseimbangan antara sikap spiritual dan sosial, pengetahuan dan keterampilan, serta menerapkannya dalam berbagai situasi di sekolah dan masyarakat (Kemendikbud, 2016).

Hasil analisis tentang pelaksanaan pembelajaran dengan menggunakan pendekatan saintifik berdasarkan kurikulum 2013 menunjukkan bahwa terdapat indikasi linier yang signifikan dengan pengetahuan awal tentang model pembelajaran dengan menggunakan pendekatan saintifik berdasarkan Kurikulum 2013 dan perencanaan pembelajaran berdasarkan kurikulum 2013, yakni padaka tegori "Cukup Mampu" dan "Mampu". Hal ini sesuai dengan pernyataan Kilic (2011) bahwa guru dengan pengetahuan kurikulum yang baik akan mampu merencanakan kegiatan pembelajaran dengan tepat. Sejalan dengan Kilic, guru matematika yang melakukan pembelajaran di kelas adalah kurikulum (Mulyasa, 2014). Namun, ada temuan data yang bertentangan dengan pernyataan Kilic (2011), peneliti menelusuri melalui wawancara dengan subjek penelitian, berikut salah satu kutipan wawancara dengan subjek penelitian.

Peneliti: "Bagaimana cara Bapak menerapkan strategi pembelajaran yang berdasarkan pendekatan saintifik?"'

Guru A: “strategi pembelajaran yang kami gunakan berdasarkan petunjuk yang ada di Buku Guru, karena sebenarnya kami belum paham betuk tentang pendekatan saintifik"

Peneliti: "Bagaimana Ibu menyampaikan materi matematika berdasarkan pendekatan saintifik?"

Guru G: "penyampain materi yang kami lakukan berdasarkan 5 M (menanya, mengamati, mengasosiasi, menalar, mengkomunikasikan). Tapi sebenanya kami masih kesulitan dalam kegiatan bertanya dan kegiatan menalar. Kami juga masih kesulitan dalam kegiatan pengamatan yang berdasarkan kurikulum 2013, karena ketika siswa diajak untuk mengamati materi tertentu masih banyak siswa yang bingung, bagaimana cara mengamati yang benar.

Peneliti: "Apa sajakah hambatan Bapak/Ibu dalam menerapkan pendekatan saintifik berdasarkan Kurikulum 2013"

Guru C: "hambatan-hambatan yang kami alami adalah pemahaman kami tentang model pembelajaran berdasarkan pendekatan saintifik masih minim, kami kesulitan dalam memahami bahasa yang ada pada buku paket, kami belum mampu dalam melaksanakan proses pembelajaran yang menuju keterampilan aplikatif, kami jarang melakukan penilaian autektik berdasarkan kurikulum 2013"

Guru D: "Hambatannya, saya kesulitan untuk memancing siswa bertanya, jadi kegiatan bertanya belum pernah terlihat di dalam kelas, Pak. Belum bisa menerapkan semua fase saintifik di dalam kelas, Pak. Belum bisa memberikan soal yang sesuai dengan kegiatan menalar yang sesungguhnya. Belum bisa membuat LKS yang sesuai dengan pendekatan saintifik. Saya merasa lebih ke teacher center bukan student center, Pak"

Berdasar hasil wawancara tersebut menunjukkan bahwa ada subjek penelitian yang belum memahami secara utuh tentang model pembelajaran dengan menggunakan pendekatan saintifik berdasarkan Kurikulum 2013, terutama penerapan kegiatan mengamati, menanya dan menalar. Padahal 
dalam menerapkan pendekatan saintifik dalam pembelajaran yang menjadi kunci terlaksananya $5 \mathrm{M}$ adalah kegiatan pengamatan dan bertanya, hal ini bertentangan dengan karakteristik kurikulum 2013. Sehingga subjek penelitian masih perlu ikut serta dalam workshop/pelatihan tentang praktik mengajar dengan menggunakan pendekatan saintifik dalam pembelajaran. Karena pelaksanaan pembelajaran berdasarkan pendekatan saintifik akan dapat berjalan baik apabila seorang guru sudah benar-benar mengetahui tentang penggunaan pendekatan saintifik dalam pembelajaran. Hal ini sesuai dengan pendapat Leonardo da Vinci (Lewis Einstein, 2008) "Mereka yang menyukai praktik tanpa teori bagaikan pelaut yang menjalankan kapal tanpa kompas dan kemudian, mereka tidak pernah tahu di mana akan terdampar." Pernyataan tersbut didukung oleh Mulyasa (2014) menyatakan bahwa guru matematika yang melakukan pembelajaran di kelas adalah kurikulum. Hal ini diperkuat juga oleh permendikbud (lampiran permendikbud no. 22, tahun 2016) bahwa dalam pengelolaan kelas Guru harus mendorong dan menghargai peserta didik untuk bertanya dan mengemukakan pendapat.

Oleh karena itu, seorang guru dalam menerapkan pendekatan saintifik harus benar-benar mempunyai pengetahuan yang cukup tentang kurikulum 2013, terampil dalam memilih strategi pembelajaran yang sesuai dengan kurikulum 2013, selalu belajar tentang bagaiaman cara menerapkan pendekatan saintifik yang tepat dan benar, dan selalu up to date tentang perkembangan kurikulum yang ada di indoensia. Menurut Zamroni (2001: 60), guru adalah orang yang memegang peran penting dalam merancang strategi pembelajaran yang akan dilakukan. Pendapat ini diperkuat oleh pernyataan Suparlan (2006: 85) yang mengatakan bahwa Standar kompetensi guru adalah ukuran yang ditetapkan atau dipersyaratkan dalam bentuk penguasaan pengetahuan dan perilaku perbuatan bagi seorang guru agar berkelayakan untuk menduduki jabatan fungsional sesuai dengan bidang tugas, kualifikasi dan jenjang pendidikan. Kedua pendapat tersebut diperkuat oleh Undang-Undang Republik Indonesia Nomor 14 tahun 2005 tentang Guru dan Dosen, "Kompetensi adalah seperangkat pengetahuan, ketrampilan dan perilaku yang harus dimiliki, dihayati dan dikuasai oleh guru atau dosen dalam melaksanakan tugas keprofesionalan".

\section{Analisis Data pada Deminsi Penyusunan dan Pelaksanaan Penilaian Autentik}

Mengacu pada Permendikbud Nomor 23 Tahun 2016, penilaian merupakan proses pengumpulan dan pengolahan informasi untuk mengukur pencapaian hasil belajar peserta didik. Pengumpulan informasi/data tentang capaian pembelajaran peserta didik dalam aspek sikap, aspek pengetahuan, dan aspek keterampilan yang dilakukan secara terencana dan sistematis yang dilakukan untuk memantau proses, kemajuan belajar, dan perbaikan hasil belajar melalui penugasan dan evaluasi hasil belajar. Penilaian yang dimaksud adalah penilaian hasil belajar oleh guru. Penilaian berfungsi untuk memantau kemajuan belajar, memantau hasil belajar, dan mendeteksi kebutuhan perbaikan hasil belajar peserta didik secara berkesinambungan. Penilaian dilaksanakan untuk memenuhi fungsi formatif dan sumatif dalam penilaian. Penilaian bertujuan antara lain untuk (a) mengetahui tingkat penguasaan kompetensi, (b) menetapkan ketuntasan penguasaan kompetensi, (c) menetapkan program perbaikan atau pengayaan berdasarkan tingkat penguasaan kompetensi, dan $(d)$ memperbaiki proses. Temuan-temuan data tentang penilaian autentik berdasarkan Kurikulum 2013 diperoleh melalui kuesioner, wawancara, dan observasi dapat disajikan pada Tabel 6.

Tabel 6. Menyusun dan melaksanakan penilaian autentik

\begin{tabular}{ccccc}
\hline No. & Guru & Skor & Prosentase & Kategori \\
\hline 1. & A & 2,60 & 65,00 & Mampu \\
2. & B & 2,60 & 65,00 & Mampu \\
3. & C & 2,45 & 61,25 & Cukup Mampu \\
4. & D & 2,30 & 57,50 & Cukup Mampu \\
5. & E & 2,40 & 60,00 & Cukup Mampu \\
6. & F & 2,40 & 60,00 & Cukup Mampu \\
7. & G & 2,20 & 55,00 & Cukup Mampu \\
\hline
\end{tabular}


Berdasarkan Tabel 6, hasil analisis tentang penyusunan dan pelaksanaan penilain autentik yang berdasarkan kurikulum 2013 memperlihatkan bahwa Guru A dan B masuk dalam kategori "Mampu". Sedangkan Guru C, D, E, F, dan G masuk dalam kategori "Cukup Mampu". Hal ini menggambarkan bahwa dalam menyusun dan melaksanakan penilain autentik yang berdasarkan kurikulum 2013 masih sangat perlu ditingkatkan. Padahal dalam RPP yang disusun oleh subjek peneliti sudah mempersiapkan instrumen penilaian yang meliputi sikap spiritual, sikap sosial, pengetahuan, dan keterampilan. Akan tetapi ketersediaan instrumen penilaian tersebut belum digunakan secar maksimal oleh subjek peneliti. Berdasarkan hasil opservasi yang peneliti temukan proses pembelajaran berlangsung, peneliti memoerhatikan seharusnya ada penilaian yang harus dituliskan pada instrumen penilaian yang telah disusun oleh subjek peneliti, yaitu pada kegiatan menanya, menggali informasi, dan berbagi (mengkomunikasikan). Subjek penelitian belum memanfaatkan instrumen penilaian yang telah disiapkan, bahkan masih ada subjek penelitian yang sama sekali belum melakukan penilaian pada saat proses pembelajaran. Hal ini bertentangan tujuan penilaian yang tercantum pada permendikbud Nomor 23 Tahun 2016 pada Bab 3 Pasal 2 bahwa penilaian hasil belajar oleh pendidik bertujuan untuk memantau dan mengevaluasi proses, kemajuan belajar, dan perbaikan hasil belajar peserta didik secara berkesinambungan. Berikut salah satu kutipan wawancara dengan subjek penelitian.

Peneliti: "Bagaimana keterlaksanaan penilaian autentik yang telah Bapak susun dalam proses pembelajaran?"

Guru G: "Instrumen penilaian yang telah disusun, belum terlaksana secara utuh berdasarkan kurikulum 2013"

Berdasarkan hasil wawancara tersebut menunjukkan bahwa ada satu subjek yang belum melaksanakan penilain autentik berdasarkan kurikulum 2013. Temuan melalui wawancara ini kalau dibiarkan akan berdampak kurang optimal dalam menerapkan pendekatan saintifik yang berdasarkan kurikulum 2013 terutama pada bagian penilaian autentik. hal ini bertentangan dengan prinsip-prinsip penulaian berdasarkan permendikbud Nomor 23 Tahun 2016 pada Bab 4 Pasal 5 poin f bahwa Prinsip penilaian hasil belajar menyeluruh dan berkesinambungan, berarti penilaian mencakup semua aspek kompetensi dengan menggunakan berbagai teknik penilaian yang sesuai, untuk memantau dan menilai perkembangan kemampuan peserta didik.

Berdasarkan hasil opservasi, peneliti menemukan bahwa penilaian yang dilakukan oleh subjek peneliti masih terbatas untuk aspek pengetahuan yang di tulis pada daftar nilai siswa yang sudah disediakan oleh sekolah. Sedangkan aspek penilaian sikap dan keterampilan rata-rata masih belum melaksanakan secara maksimal.

\section{Analisis Data pada Deminsi Respon Siswa salama Guru PPL Magang}

Kegiatan belajar-mengajar merupakan suatu proses interaksi antara peserta didik dan guru yang di dalamnya terdapat kegiatan yang bertujuan untuk membimbing dan memberikan pengetahuan baru pada siswa. UUSPN No. 20 tahun 2003 (Syaiful Sagala, 2006: 62) menyatakan pembelajaran adalah proses interaksi peserta didik dengan guru dan sumber belajar pada suatu lingkungan belajar. Sejalan dengan pernyataan tersebut, Wina Sanjaya (2006: 51) menyatakan bahwa pembelajaran adalah kegiatan yang bertujuan,yaitu membelajarkan siswa. Kedau pernyataan tersebut diperkuat oleh Abdul Majid (2013: 5) dalam bukunya menyebutkan bahwa ciri-ciri dari pembelajaran yaitu a) ada tujuan yang ingin dicapai, b) ada pesan yang akan di transfer, c) pelajar, d) guru, e) metode, f) situasi, g) penilaian. Sehingga proses pembelajaran merupakan rangkaian kegiatan yang melibatkan berbagai komponen. Pembelajaran pada hakikatnya merupakan suatu proses interaksi antara guru dengan siswa, baik interaksi secara langsung seperti kegiatan tatap muka maupun secara tidak langsung, yaitu dengan menggunakan berbagai pola pembelajaran (Rusman, 2012: 134). Siswa merupakan salah satu komponen penting dalam kegiatan pembelajaran. Pembelajaran tidak akan bisa berjalan jika tidak ada siswa yang akan belajar. Di dalam bukunya Hamzah (2011: 2) menyatakan bahwa dalam belajar, siswa tidak hanya berinteraksi dengan guru sebagai salah satu sumber belajar, tetapi mungkin berinteraksi dengan keseluruhan sumber belajar yang dipakai untuk mencapai tujuan pembelajaran yang dipakai. Temuan-temuan data tentang respon siswa terhadap Guru PPL selama mereka magam di SMP Negeri Jember diperoleh melalui kuesioner, wawancara, dan observasi dapat disajikan pada Tabel 7. 
Tabel 7. Respon siswa terhadap guru PPL selama mengajar (magang)

\begin{tabular}{ccccc}
\hline \multicolumn{1}{c}{ No. } & Guru & Skor & Prosentase & Kategori \\
\hline 1. & A & 3,25 & 81,25 & Sesuai \\
2. & B & 3,22 & 80,58 & Sesuai \\
3. & C & 3,55 & 88,67 & Sangat Sesuai \\
4. & D & 3,20 & 79,92 & Sesuai \\
5. & E & 3,09 & 77,25 & Sesuai \\
6. & F & 3,41 & 85,17 & Sangat Sesuai \\
\hline 7. & G & 3,43 & 85,83 & Sangat Sesuai \\
\hline
\end{tabular}

Berdasarkan Tabel $7 \mathrm{di}$ atas, hasil analisis respon siswa terhadap calon guru matematika tentang dengan menggunakan model pembelajaran melalui pendekatan saintifik berdasarkan Kurikulum 2013 memperlihatkan bahwa Guru A, B, D, dan E masuk dalam kategori "Sesuai". Sedangkan Guru C, F, an G masuk dalam kategori "Sangat Sesuai”. Hal ini menggambarkan bahwa Guru PPL selama mengajar dengan model pembelajaran yang digunakan dapat respon positif dan dapat diterima baik oleh siswa. Hal ini sesuai dengan pendapat yang dikemukakan oleh Piaget (Nursalim, 2007: 74) bahwa anak berusaha membangun secara aktif dunia kognitif mereka sendiri, sehingga anakanak akan berusaha beradaptasi dengan informasi baru yang diperolehnya, serta dapat meningkatkan sumber daya manusia (SDM) di Indonesia dalam menghadapi masyarakat ekonomi asia (MEA). Akan tetapi ada dua temuan pada hasil wawancara yang bertentangan dengan pendapat Piaget, berikut salah satu kutipan wawancara dengan subjek penelitian.

Peneliti: "apakah guru PPL mengatur tempat duduk berdasarkan karakteristik proses pebelajaran?"

Siswa-1: "selama kami diajar oleh guru PPL, tempat duduk kami belum pernah diatur berdasarkan karakteristik proses pebelajaran"

Peneliti: "Bagaimana volume dan intonasi suara guru dalam proses pembelajaran?"

Siswa-2: "kami yang duduk di belakang seringkali tidak mendengar suara dengan jelas apa yang sedang dibahas oleh Guru PPL"

Berdasarkan hasil wawancara tersebut menunjukkan bahwa ada beberapa subjek penelitian yang belum sesuai dengan Permendikbut No. 22 Tahun 2016 tentang pengelolaan kelas yang terdapat pada bab IV point 4c, Guru menyesuaikan pengaturan tempat duduk peserta didik dan sumber daya lain sesuai dengan tujuan dan karakteristik proses pembelajaran. Pada bab IV point 4d, volume dan intonasi suara guru dalam proses pembelajaran harus dapat didengar dengan baik oleh peserta didik. Oleh karena itu, subjek penelitian perlu melakukan evaluasi diri agar kegiatan pembelajaran selalau dapat diterima dengan baik siswa, sehingga terwujudnya pendekatan saintifk dalam pembelajaran yang sesuai dengan kuirkulum 2013.

\section{Hambatan calon guru matematika dalam menerapkan pendekatan saintifik berdasarkan Kurikulum 2013}

Melaksanakan kegiatan pembelajaran dengan menggunakan pendekatan saintifik merupakan suatu tantangan tersendiri bagi seorang guru, apalagi masih calon guru. Sehingga dalam pelaksanaannya dapat dipastikan akan mengalalami hambatan-hambatan pada bagain-bagian tertentu. Kegagalan pembelajaran di kelas terkadang disebabkan ketidaktahuan guru mengenai hambatan pembelajaran yang mungkin terjadi. Dimana salah satu hambatan yang dialami oleh guru adalah kemampuan siswa yang beragam, siswa belum terbiasa dengan pembelajaran pendekatan konstruktivisme, kurang cukupnya 
waktu pembelajaran, dan kurangnya sarana belajar berupa buku yang sesuai dengan Kurikulum 2013. Hal ini akan menjadi lebih rumit jika guru belum memahami sepenuhnya Kurikulum 2013, termasuk proses pembelajaran sekaligus muatan isinya sebagai bahan yang dibahas dalam pembelajaran. Hasil penelitian ini sejalan dengan penelitian Eraslan (2013) dan Syomwene (2013), dan Mizzi (2013). Pelaksanaan penilaian, baik proses dan hasil belajar serta menyusun laporan hasil belajar menggunakan Kurikulum 2013 merupakan kendala yang paling besar. Kendala ini disebabkan adanya empat kompetensi yang dinilai, yaitu kompetensi sikap spiritual (KI-1), kompetensi sikap sosial (KI-2), kompetensi pengetahuan (KI-3) dan kompetensi keterampilan (KI-4). Teknik penilaian yang digunakan juga sangat banyak. Sehingga dengan banyaknya tugas guru yang harus dilakukan akan megalami kesulitan-kesulitan dalam penerapnnya. Guru dengan pengetahuan yang kuat mengenai kesulitan pembelajaran cenderung memiliki metode pembelajaran dan menyadari cara untuk mengatasi hambatan tersebut. Adapun temuan-temuan hambatan yang dialami oleh subjek peneliti dalam menerapkan pembelajaran dengan menggunakan pendekatan saintifik yang sesuai dengan Kurikulum 2013 diperoleh melalui kuesioner, pertanyaan, dan wawancara dapat disajikan pada Tabel 8 berikut.

Tabel 8. Hambatan dalam menerapkan pendekatan saintifik berdasarkan Kurikulum 2013

\begin{tabular}{|c|c|}
\hline Guru & Hambatan-hambatan \\
\hline A & $\begin{array}{l}\text { Hambatan-hambatan yang dialami oleh subjek penelitian adalah pemahaman tentang } \\
\text { model pembelajaran berdasarkan pendekatan saintifik masih minim, kami kesulitan } \\
\text { dalam memahami bahasa yang ada pada buku paket, kami belum mampu dalam } \\
\text { melaksanakan proses pembelajaran yang menuju keterampilan aplikatif, kami jarang } \\
\text { melakukan penilaian autektik berdasarkan kurikulum } 2013\end{array}$ \\
\hline $\mathrm{B}$ & $\begin{array}{l}\text { Hambatan-hambatan yang dialami oleh subjek penelitian adalah kurangnya } \\
\text { pemahaman tentang penerapan pendekatan saintifk pada pembelajaran, kesulitan } \\
\text { dalam mengatur alokasi waktu dengan materi yang diajarkan, dan kesulitan dalam } \\
\text { menyusun dan melaksanakan penilaian autentik berdasarkan kurikulum } 2013 \text {. }\end{array}$ \\
\hline $\mathrm{C}$ & $\begin{array}{l}\text { Hambatan-hambatan yang dialami oleh subjek penelitian adalah hambatannya lebih } \\
\text { pada penerapan pendekatan saintifiknya, kesulitan dalam menginovasi dan kreasi } \\
\text { dalam kegiatan belajar mengajar di dalam kelas, kesulitan dalam menerapkan } \\
\text { penilaian sikap, pengetahuan, keterampilan pada instrumen penilaian. }\end{array}$ \\
\hline $\mathrm{D}$ & $\begin{array}{l}\text { Hambatan-hambatan yang dialami oleh subjek penelitian adalah kesulitan untuk } \\
\text { memancing siswa bertanya sehingga kegiatan bertanya belum pernah terlihat dengan } \\
\text { jelas di dalam kelas, belum bisa menerapkan semua fase saintifik di dalam kelas, } \\
\text { belum bisa memberikan soal yang sesuai dengan kegiatan menalar yang } \\
\text { sesungguhnya, dan bisa membuat LKS yang sesuai dengan pendekatan saintifik. } \\
\text { Sunjek penelitian merasa lebih ke teacher center dari pada student center. }\end{array}$ \\
\hline $\mathrm{E}$ & $\begin{array}{l}\text { Hambatan-hambatan yang dialami oleh subjek penelitian adalah masih kesulitan } \\
\text { dalam hal penilaian siswa, yang disebabkan oleh masih terdapatnya guru dengan } \\
\text { kompetensi pedagogik dan kompetensi profesionalime yang kurang baik, serta } \\
\text { pentingnya analisis buku guru dan buku siswa jika di dalam buku tersebut ditemukan } \\
\text { adanya ketidaktepatan dan kekeliruan, guru dapat mengatasi dengan melakuakan } \\
\text { langkah-langkah tindak lanjut yang diperlukan, peran guru menjadi sangat penting, } \\
\text { sebelum menggunakan di kelas, tentunya guru diharapkan sudah membaca dan } \\
\text { mencermati dengan melakukan analisis buku terlebih dahulu. }\end{array}$ \\
\hline $\mathrm{F}$ & $\begin{array}{l}\text { Hambatan-hambatan yang dialami oleh subjek penelitian adalah kesulitan dalam } \\
\text { memahami isi buku paket, kurang memahami tujuan Kurikulum } 2013 \text { dan } \\
\text { pendekakatan saintifik, kurang mampu melaksanakan proses pembelajaran yang } \\
\text { menuju keterampilan aplikatif, kurang mampu melakukan proses pembelajaran yang } \\
\text { membuat peserta didik menjadi ingin melakukan pengamatan dan eksperimen, kurang } \\
\text { mampu melakukan proses pembelajaran yang menumbuhkan kreatifitas peserta didik. }\end{array}$ \\
\hline G & $\begin{array}{l}\text { Hambatan-hambatan yang dialami oleh subjek penelitian adalah kurang pengetahuan } \\
\text { tentang menyusun perencanaan pembelajaran, kesulitan untuk menangani perbedaan } \\
\text { kemampuan matematika peserta didik yang seharusnya menjadi pemicu kesadaran } \\
\text { untuk memahami berbagai strategi alternatif dalam pemberian konsep, latihan, atau } \\
\text { membangun lingkungan belajar yang kondusif, dan kesulitan mengalokasikan waktu } \\
\text { untuk melakukan penilaiansaat berlangsungnya pembelajaran. }\end{array}$ \\
\hline
\end{tabular}


Berdasarkan Tabel 8 di atas, hasil analisis hambatan calon guru matematika dalam menerapkan pendekatan saintifik berdasarkan Kurikulum 2013 memperlihatkan ada kesulitan pada setiap deminsi, yaitu pada deminsi pengetahuan tentang pendekatan saintifik, pada deminsi perencanaan pembelajaran, pada deminsi pelaksanaan pembelajaran, pada deminsi penyusunan dan pelaksanaan penilaian autentik. Hal ini disebabkan minimnya pengetahuan dan praktek tentang pendekatan saintifik dalam pembelajaran. Oleh karena itu, subjek penelitian perlu mengikuti pelatihan/workshop tentang kurikulum 2013, subjek penelitian harus lebih banyak belajar dan membaca tentang pendekatan saintifik berdasarkan kurikulum 2013, subjek penelitian harus lebih kreatif dalam menerapkan model pembelajaran yang berpusat pada siswa, kemampuan subjek penelitian dalam bidang teknologi, informasi dan komunikasi harus ditingkatkan dengan mengikuti workshop/pelatihan.

\section{Kesimpulan}

Berdasarkan hasil penelitian yang diperoleh melalui analisis dan pembahasan tentang "Analisis kemampuan Calon Guru Matematika dalam Menerapkan Pendekatan Saintifik Berdasarkan Kurikulum 2013" adalah sebagai berikut:

1. Pengetahuan tentang penerapan pendekatan saintifik pada pembelajaran berdasarkan kurikulum 2013 sebanyak lima orang subjek penelitian yang masuk dalam kategori "Cukup Mampu” dan dua orang subjek penelitian yang masuk dalam kategori "Mampu".

Secara lebih rinci, ada empat point yang dapat peneliti temukan:

a) subjek penelitian belum memiliki pengetahuan matematika yang cukup mumpumi dalam memahami materi yang ada di buku paket.

b) subjek penelitian belum memahami secara utuh tentang karakteristik kurikulum 2013 yang sebenarnya

c) subagian besar subjek penelitian belum memahami perbedaan kurikulum 2013 dengan kurikulum lainnya.

d) subjek penelitian belum memahi secara utuh tentang penerapan pendekatan saintifk pada pembelajaran

2. Kemampuan tentang perencanaan pembelajaran berdasarkan kurikulum 2013 sebanyak tujuh orang subjek penelitian atau semua subjek penelitian masuk dalam kategori "Mampu"

Secara lebih rinci, ada empat point yang dapat peneliti temukan:

a) perumusan tujuan pembelajaran, indikator dan konsep materi ajar oleh subjek penelitian belum sesuai dengan Kompetensi Dasar yang ingin dicapai.

b) dalam penyusunan RPP subjek penelitian sudah menggunakan model pembelajaran yang dianjurkan dalam Kurikulum 2013

c) penyusunan langkah-langkah model pembelajaran yang dipadukan dengan pendekatan saintifik dituliskan dengan baik oleh subjek penelitian pada RPP.

d) penyusunan contoh-contoh soal dan soal latihan yang disusun oleh subjek penelitian pada RPP masih selalu perlu diperbaiki.

3. Kemampuan tentang pelaksanaan pembelajaran dengan menggunakan pendekatan yang sesuai dengan kurikulum 2013 sebanyak tiga orang subjek penelitian yang masuk dalam kategori "Cukup Mampu" dan empat orang subjek penelitian yang masuk dalam kategori "Mampu".

Secara lebih rinci, ada lima point yang dapat peneliti temukan:

a) subjek penelitian belum mampu secara utuh dalam menyajikan pembelajaran dengan pendekatan saintifik

b) masih minimnya pertanyaan penelusuran oleh subjek penelitian saat berlangsungnya pembelajaran,

c) subjek penelitian masih belum mengaitkan kondisi kontekstual dalam pembelajaran,

d) dalam menerapkan pendekatan saintifik subjek penelitian masih berpatokan pada buku paket, sehingga minim kreatisfitas dalam materi pelajaran,

e) pesan karakter kepada peserta didik belum dilakukan subjek penelitian yang bersumber dari nilainilai matematika.

4. Kemampuan tentang penyusunan dan pelaksanaan penilaian autentik berdasarkan kurikulum 2013 sebanyak lima orang subjek penelitian yang masuk dalam kategori "Cukup Mampu” dan dua orang subjek penelitian yang masuk dalam kategori "mampu".

Secara lebih rinci, ada empat tiga yang dapat peneliti temukan:

a) minimnya ketersediaan instrumen penilaian saat pembelajaran di kelas, 
b) subjek penelitian menilai peserta didik saat proses pembelajaran dituangkan pada selembar kertas atau sekedar mengingatnya, dan

c) penilaian otentik belum terlihat jelas dilakukan oleh subjek penelitian karena ketidakmatangan dalam pengaturan alokasi waktu.

5. Kesesuian tentang respon siswa salama subjek penelitian mengajar berdasarkan pendekatan saintifk yang berdasarkan kurikum 2013 sebanyak empat orang subjek penelitian yang masuk dalam kategori "Sesuai" dan tinga orang subjek penelitian yang masuk dalam kategori "Sangat Sesuai".

Secara lebih rinci, ada dua point yang dapat peneliti temukan:

a) Subjek penelitian belum bisa mengatur tempat duduk berdasarkan karakteristik proses pebelajaran

b) volume dan intonasi suara guru dalam proses pembelajaran harus belum dapat didengar dengan baik oleh peserta didik

6. Hambatan-hambatan oleh subjek penelitian dalam menerapkan pendekatan saintifik berdasarkan Kurikulum 2013.

Secara lebih rinci, hambatan-hambatan yang dapat peneliti temukan:

a) pemahaman tentang model pembelajaran berdasarkan pendekatan saintifik masih minim, kami kesulitan dalam memahami bahasa yang ada pada buku paket, kami belum mampu dalam melaksanakan proses pembelajaran yang menuju keterampilan aplikatif, kami jarang melakukan penilaian autektik berdasarkan kurikulum 2013,

b) kurangnya pemahaman tentang penerapan pendekatan saintifk pada pembelajaran, kesulitan dalam mengatur alokasi waktu dengan materi yang diajarkan, dan kesulitan dalam menyusun dan melaksanakan penilaian autentik berdasarkan kurikulum 2013,

c) hambatannya lebih pada penerapan pendekatan saintifiknya, kesulitan dalam menginovasi dan kreasi dalam kegiatan belajar mengajar di dalam kelas, kesulitan dalam menerapkan penilaian sikap, pengetahuan, keterampilan pada instrumen penilaian,

d) kesulitan untuk memancing siswa bertanya sehingga kegiatan bertanya belum pernah terlihat dengan jelas di dalam kelas, belum bisa menerapkan semua fase saintifik di dalam kelas, belum bisa memberikan soal yang sesuai dengan kegiatan menalar yang sesungguhnya, dan bisa membuat LKS yang sesuai dengan pendekatan saintifik. Sunjek penelitian merasa lebih ke teacher center dari pada student center,

e) kesulitan dalam hal penilaian siswa, yang disebabkan oleh masih terdapatnya guru dengan kompetensi pedagogik dan kompetensi profesionalime yang kurang baik, serta pentingnya analisis buku guru dan buku siswa jika di dalam buku tersebut ditemukan adanya ketidaktepatan dan kekeliruan, guru dapat mengatasi dengan melakuakan langkah-langkah tindak lanjut yang diperlukan, peran guru menjadi sangat penting, sebelum menggunakan di kelas, tentunya guru diharapkan sudah membaca dan mencermati dengan melakukan analisis buku terlebih dahulu,

f) kesulitan dalam memahami isi buku paket, kurang memahami tujuan Kurikulum 2013 dan pendekakatan saintifik, kurang mampu melaksanakan proses pembelajaran yang menuju keterampilan aplikatif, kurang mampu melakukan proses pembelajaran yang membuat peserta didik menjadi ingin melakukan pengamatan dan eksperimen, kurang mampu melakukan proses pembelajaran yang menumbuhkan kreatifitas peserta didik,

g) kurang pengetahuan tentang menyusun perencanaan pembelajaran, kesulitan untuk menangani perbedaan kemampuan matematika peserta didik yang seharusnya menjadi pemicu kesadaran untuk memahami berbagai strategi alternatif dalam pemberian konsep, latihan, atau membangun lingkungan belajar yang kondusif, dan kesulitan mengalokasikan waktu untuk melakukan penilaiansaat berlangsungnya pembelajaran.

\section{Daftar Pustaka}

Abdul Majid. (2013). Strategi Pembelajaran. Bandung: Rosda Karya.

As'ari, Abdurrahman. 2014. Berbagai Permasalahan Pembelajaran Matematika dalam Kurikulum 2013 dan Beberapa Upaya untuk Mengatasinya. Makalah disajikan dalam Seminar Nasional: Solusi Problematika Implementasi Kurikulum 2013 untuk Mewujudkan Pembelajaran Matematika yang Berkualitas, Program Studi Pendidikan Matematika Universitas Jember, Jember, 16 Maret.

As'ari, Abdurrahman. 2015. Mewujudkan Pendekatan Saintifik dalam Kelas Matematika. UM Malang.

Dahar, R.W. 1991. Teori-teori Belajar. Jakarta: Erlangga.

Department of Education. 2002. Revised National Curriculum Statement Grades R-9 (Schools) Policy, Arts and Culture. Pretoria: Government Printer. 
Endang Mulyani. 2013. Pembelajaran Scientific dalam Kurikulum 2013. Yogyakarta: Fakultas EkonomiUniversitas Negeri Yogyakarta.

Hamzah B. Uno. 2011. Perencanaan Pembelajaran. Jakarta: Bumi Aksara.

Kemdikbud, 2014. Peraturan Menteri Pendidikan dan Kebudayaan, No. 103, tahun 2014. Jakarta: Kementerian Pendidikan dan Kebudayaan.

Kemdikbud. 2015. Materi Pelatihan Guru Implementasi Kurikulum 2013 Jenjang SMP Tahun 2015. Jakarta.

Nurhamidah, Sitim dkk. 2014. Upaya Peningkatan Pengelolaan Proses Pembelajaran Melalui Pendampingan pada Implemntasi Kurikulum 2013 terhadap Guru-guru Kelas I dan IV. e- Journal Program Pascasarjana Universitas Pendidikan Ganesha Program Studi Pendidikan Dasar (Volume 4 Tahun 2014).

Mulyasa. 2015. Pengembangan dan Implementasi Kurikulum 2013. Bandung: PT. Remaja Rosdakarya

Ozlem Dogan Temur. 2012. Analysis of Prospective Classroom Teachers' Teaching of Mathematical Modeling and Problem Solving. Eurasia Journal of Mathematics, Science \& Technology Education, 2012, 8(2), 83-93

Permendikbud. 2016. Peraturan Menteri Pendidikan dan Kebudayaan Republik Indonesia Nomor 20 Tahun 2016 tentang Standar Proses Pendidikan Dasar dan Menengah.

Permendikbud. 2016. Peraturan Menteri Pendidikan dan Kebudayaan Republik Indonesia Nomor 23 Tahun 2016 tentang Standar Penilaian Pendidikan.

Rusman. 2012. Model-model PembelajaranMengembangkan Profesionalisme Guru. Jakarta: Raja Grafindo Persada.

Sulaiman. 1979. Pengantar Teori dan Praktek Pengajaran. Semarang: IKIP Semarang Press.

Sugiyono. 2013. Metode Penelitian Pendidikan. Bandung: Alfabeta.

Sunardi, 2016. Startegi Penguatan Pengembangan 4C's dalam Pembelajaran Matematika. Prosiding Seminar Nasional Pendidikan Matematika Pascasarjana Universitas Negeri Malang

Sosilo, Ahmadi, dkk. 2015. Analisis Kemampuan Guru Matematika dalam Mengiplimentasikan Kurikulum 2013 di Kota Semarang. Unnes Journal of Mathematics Education Research. Universitas Negeri Semarang

Tohir, Mohammad. 2016. Peningkatan Kemampuan Guru dalam Mengiplimentasikan Kurikulum 2013 di MTs Raudlatul Hasanah Pamekasan. Yayasan Pendidikan Islam Al-Hasanah.

Tohir, Mohammad. 2016. Penerapan Pendekatan Saintifik pada Pembelajaran Matematika Ditinjau dari Sikap Kritis Siswa Kelas VIII MTs Raudlatul Hasanah Pamekasan. Yayasan Pendidikan Islam AlHasanah.

Tohir, Mohammad. 2016. Menjadikan Para Siswa Aktif Bertanya dalam Kelas Matematika Berdasarkan Kurikulum 2013. Prosiding Seminar Nasional Matematika dan Pembelajarannya: Peluang Matematika dan Pembelajarannya dalam Menghadapi Masyarakat Ekonomi ASEAN (MEA). Pendidikan Matematika FKIP Universitas Jember.

Usman, M.U.1992. Menjadi Guru Profesional. Bandung: Remaja Rosda Karya. 